Bangladesh J. Bot. 43(3): 301-308, 2014 (December)

\title{
FOUR NEW RECORDS OF ACROCARPOUS MOSSES FOR BANGLADESH
}

\author{
Md Saidur Rahman* and Hamida Khatun \\ Department of Botany, University of Dhaka, Dhaka-1000, Bangladesh
}

Key words: Fissidens taxifolius, F. involutus, Hyophila perannulata, H. rosea, Acrocarpous mosses

\begin{abstract}
Two species from each of the genus Fissidens Hedw. and Hyophila Brid. are dealt with. The species are Fissidens taxifolius Hedw., F. involutus Wils. ex Mitt., Hyophila perannulata Ren. et Card. and H. rosea Williams reportd as new to the Acrocarpous moss flora of Bangladesh. A detailed taxonomic description of each species with location, date of collection, name of collector and artificial keys of species are provided.

\section{Introduction}

A reasonable good amount of works have been done on mosses of Bangladesh. Tixer (1967) collected and reported many mosses from Chittagong and Cox's Bazar districts of Bangladesh. Hadiuzzaman (1984a) reported 10 species among them nine were new for the country and in (1984b) he published four species of the genus Calymperes Schwaerg. of which three were new records for Bangladesh. Banu (1991) worked on Acrocarpous mosses of Bangladesh. She identified 96 taxa of which 77 were new report from Bangladesh which included three new species i.e, Fissidens hadii, Calymperes hazarikhilense and Splachnobryum schofieldii and two new varieties; Fissidens sylvaticus var. ramosus and Splachnobryum flaccidum var. navicularis. These five taxa were recorded as new to science. Khatun (2002) worked on Pleurocarpous mosses of Bangladesh. She identified 72 taxa of them 62 were reported for the first time from Bangladesh and the species Vesicularia retiformis as new to science.

In the present paper two species of the genus Fissidens Hedw. and two species of the genus Hyophila Brid. described that are new record for Bangladesh.

\section{Materials and Methods}

The report is based upon fresh materials collected from Boldha garden, Dhaka. Boldha garden consists of 2 units named as 'Psyche' and 'Cybele'. The soil is sandy loam to clay type with a pH 6.7 and annual average temperature is maximum $34.5^{\circ} \mathrm{C}$ and minimum $11.5^{\circ} \mathrm{C}$. The average rainfall is about $194 \mathrm{~cm}$. Boldha Garden represents dense vegetation of Bryophytes.

Collected fresh materials from Boldha Garden were analyzed, morphological and anatomical features of the specimens as well as other important features were drawn with the help of cameralucida and measured them with the help of previously calibrated oculometer. Species were identified with the help of the book 'Mosses of eastern India and adjacent regions' written by Gangulee (1969-1980). All the specimens collected were preserved in the Bryology Herbarium, Department of Botany, University of Dhaka (DUBH).
\end{abstract}

*Author for correspondence: Bangladesh Council of Scientific and Industrial Research Laboratories Chittagong, Chittagong-4220, Bangladesh. <saidurgene@yahoo.com>. 


\section{Results and Discussion}

The present study comprises of four species F. taxifolius Hedw., F. involutus Wils., ex Mitt., $H$. perannulata Ren. et Card. and $H$. rosea Williams under two genera; Fissidens Hedw. and Hyophila Brid., two orders; Fissidentales and Pottiales, under two Families; Fissidentaceae and Pottiaceae of the class Bryopsida.

Banu-Fattah (1995b, 1998, 2005a,b), Banu-Fattah and Hadiuzzaman (1993, \#1994b, 1995a, 1996a,b,c, 1997, 1998a,b,c, 1999, 2003a,b, 2004, 2006a,b) and Banu-Fattah and Jagdish (1998) on Acrocarpous mosses of Bangladesh published a series of publication of which some were collected from Boldha garden. Khatun and Hadiuzzaman (1994, 1995, 2003, 2004, 2005, 2006, 2007a,b) published Pleurocarpous mosses of Bangladesh and some of them were collected from Boldha garden. Kamruzzaman (1995) gave an illustrated account of 45 species of Riccia L. which was later included by Hadiuzzaman (2007) in the Encyclopedia of Flora and Fauna of Bangladesh vol-5, three of which were collected from this garden.

The present study an extensive collection and work added four Acrocarpous mosses to the Mosses Flora of Bangladesh as well as indicated that Boldha garden, Dhaka is rich in Bryophyte flora.

A detailed taxonomic description and important features of four species are given in the following section.

\section{Taxonomic enumeration}

Class: Bryopsida; Order: Fissidentales; Family: Fissidentaceae

Genus: Fissidens Hedw. Sp. Musc. 152 (1801)

\section{Key to the species:}

1. Costa short excurrent, leaf border cells dentate

Costa percurrent, leaf border cells not conspicuously dentate
1. F. taxifolius

2. F. involutus

1. Fissidens taxifolius. Hedw. in Sp. Musc.155 (1801)

Dicranum taxifolium (Hedw.) Web. et Mohr. in Ind. Mus. P1. Crypt. : 2 (1803)

Plants yellow green to green in colour. Stem $\pm 1.55 \mathrm{~cm}$ long and $3 \mathrm{~mm}$ broad with leaves and contains 18 - 22 pairs of leaves. Leaves not much crumpled when dry, oblong-lingulate, broadly acuminate, $\pm 1.67 \mathrm{~mm}$ long and $\pm 0.48 \mathrm{~mm}$ broad. Sheathing lamini usually unequal (open), \pm 1.09 $\mathrm{mm}$ long and $\pm 0.274 \mathrm{~mm}$ broad ( $\pm 2 / 3$ of the whole leaf). Apical part usually symmetrical. Costa deep brown in colour, $\pm 45 \mu \mathrm{m}$ wide at base, short excurrent, the tip ending in short apiculus. Leaf border cells dentate, $\pm 9.76 \times 5.98 \mu \mathrm{m}$, and slightly irregular but differentiated up to leaf base. The marginal laminal cells are smaller. Laminal cells irregularly quadrate-hexagonal, upper laminal cells $\pm 10.35 \times 7.42 \mu \mathrm{m}$, middle laminal cells $\pm 9.13 \times 8.1 \mu \mathrm{m}$, and basal laminal cells $\pm 10.35 \times$ $6.97 \mu \mathrm{m}$. Sporophyte not found.

Specimens examined: Southern side of the circular structure in Psyche part, on brick, Md. Saidur Rahman, 10.12. 2006, 33, 4a, (DUBH).

Distribution: India, China, UK, Newzealand, USA, Australia, Sweden, Spain and Canada. 


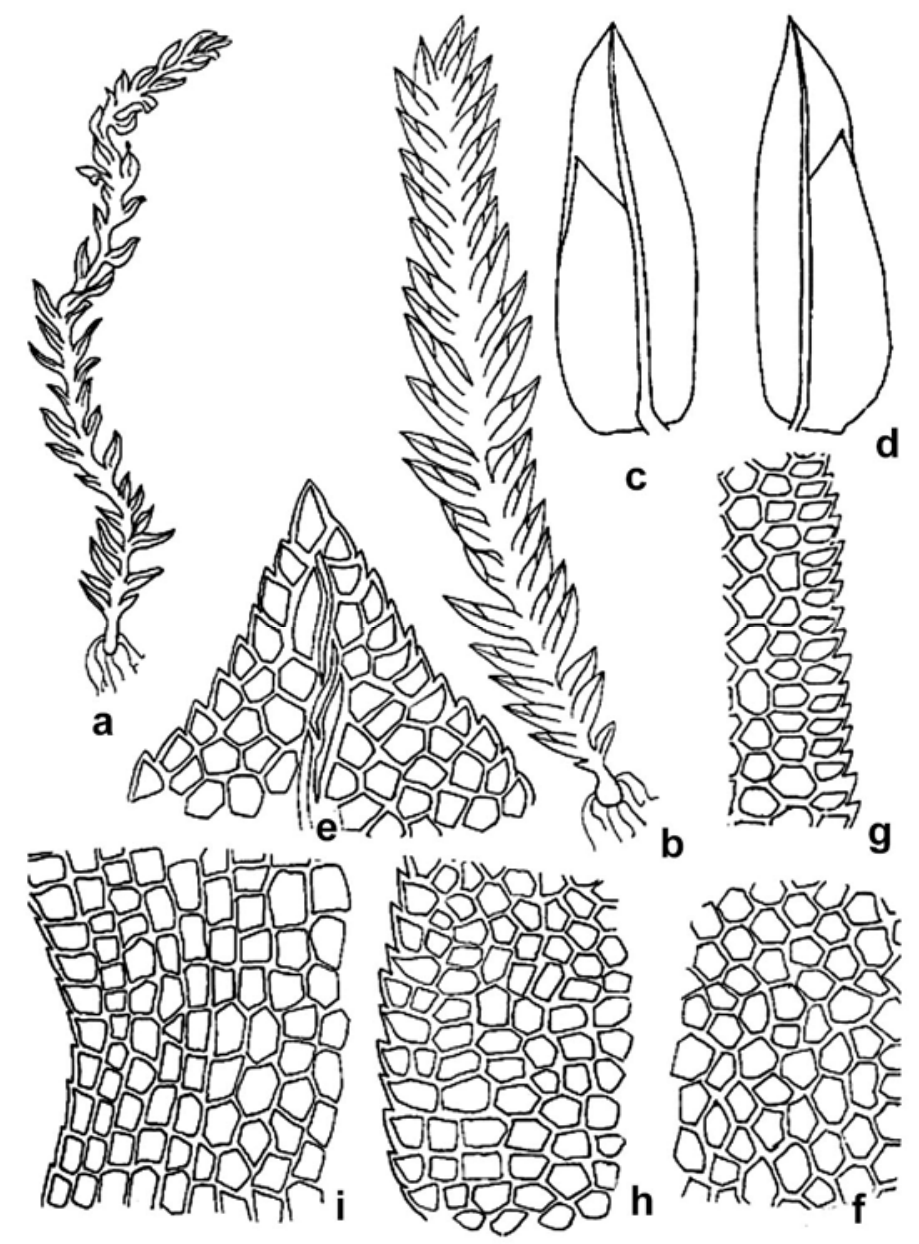

Fig. 1a-i: Fissidens taxifolius. Hedw. a. Dry plant $(\times 5)$, b. wet plant $(\times 5)$, c-d. leaves $(\times 15)$, e. apex of leaf $(\times 225)$, f. middle laminal cells $(\times 225)$, g. marginal cells of lamina $(\times 225)$, h. basal cells of dorsal lamina $(\times 225)$, i. basal cells of sheathing lamina $(\times 225)$.

2. Fissidens involutus Wils. ex Mitt. in Musc. Ind. Or.: 138 (1859)

F. involutus Wils. in Kew J. Bot., 9 : 294 (1857)

Plants yellow-green, $\pm 4.5 \mathrm{~mm}$ long and $\pm 2.0 \mathrm{~mm}$ wide with 6-8 pairs of leaves. Leaves ovate-lanceolate, tip acuminate, $\pm 1.24 \mathrm{~mm}$ long and $0.25 \mathrm{~mm}$ wide. Sheathing lamini open, \pm 0.67 $\mathrm{mm}$ long and $\pm 0.14 \mathrm{~mm}$ wide. Apical lamini symmetrical or bent. Dorsal lamina sharply or slowly rounded at base ending at attachment. Axillary glandular cells completely absent. Costa brown, $\pm 21.6 \mu \mathrm{m}$ broad at base, percurrent, ending a few cells below apex. Leaf marginal cells $\pm 8.1 \times 5.4 \mu \mathrm{m}$. Apical cells of leaf rectangular-hexagonal, $\pm 6.61 \times 6.03 \mu \mathrm{m}$, middle laminal cells pentagonal-hexagonal, $\pm 6.16 \times 5.80 \mu \mathrm{m}$, leaf basal cells rectangular-hexagonal, $\pm 6.61 \times 5.58 \mu \mathrm{m}$. A row or slightly larger transversely placed margin cells which sometimes look lighter in colour. Sporophytes not found. 
Specimens examined: South side of the lion gate in Cybele part, on brick, Md. Saidur Rahman, 10. 12. 2006, 4b, (DUBH).

Distribution: India, China, Myanmar, Papua New Guinea, Chile and Taiwan.

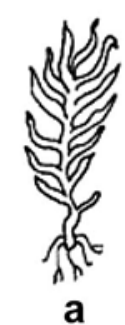

a

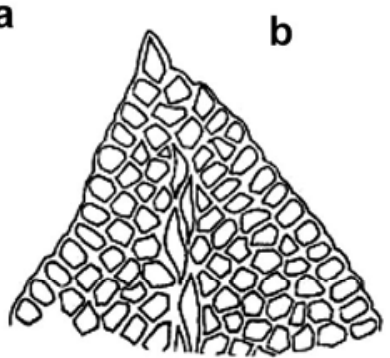

e

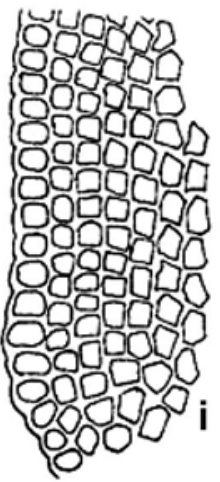

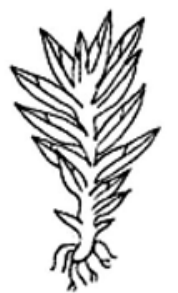

b

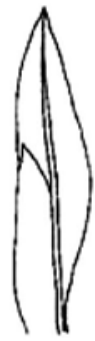

C

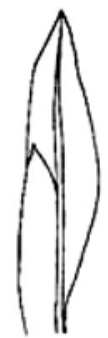

d

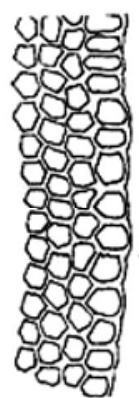

g

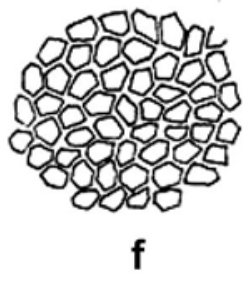

Fig. 2a-i. Fissidens involutus Wils. ex Mitt. a. Dry plant $(\times 5)$, b. wet plant $(\times 5)$, c-d. leaves $(\times 15)$, e. apex of leaf $(\times 225)$, f. middle laminal cells $(\times 225)$, g. marginal cells of leaf $(\times 225)$, h. basal cells of dorsal lamina $(\times 225)$, i. basal cells of sheathing lamina $(\times 225)$

Order: Pottiales; Family: Pottiaceae

Genus: Hyophila Brid. Bryol. Univ. 1 : 760 (1827)

Plant dioicous, usually small, in dense tuft. Leaves with inrolled margin when dry, oblonglingulate or spathulate, apex broadly acuminate. Costa strong, ending below apex or percurrent, sometimes short-excurrent. Basal laminal cells rectangular, hyaline, upper laminal cells small, mamillose or papillose. Seta apical, erect, slender, long. Capsule erect, cylindrical. Peristome absent. At the apex of upper leaf numerous gemmae present. 


\section{Key to the species:}

1. Costa short excurrent and non papillate

Costa percurrent and papillate

\section{H. perannulata}

2. H. rosea

1. Hyophila perannulata Ren. et Card. in Bull. Soc. R. Bot. Belg., 34 (2): 60 (1896)

Hyophila decolyii Broth. In Par. in Index Bryol. Suppl. 190 (1900)

Plants dioicous, tufted, green, usually unbranched, $\pm 5.1 \mathrm{~mm}$ long, showing rosette appearance. Leaves broadly lingulate, erectopatent to spreading, curled and involute when dry, $\pm 2.09 \mathrm{~mm}$ long and $\pm 0.72 \mathrm{~mm}$ broad, apex broadly acuminate in mucro, leaf margin usually flat and unbroken when moist, not denticulate, about $1 / 3$ of leaf base hyaline cells nonpapillate. Costa light brown, $\pm 81 \mu \mathrm{m}$ wide at base, excurrent. Upper laminal cells chlorophyllose, irregularly rounded-hexagonal, multipapillate, obscure, $\pm 9.9 \times 6.7 \mu \mathrm{m}$. Leaf base formed of lax, thin walled, smooth, pellucid cells, $\pm 51.30 \times 10.80 \mu \mathrm{m}$ near base of costa, becoming shorter and narrower towards margin. Middle laminal cells rectangular to hexagonal, $\pm 8.86 \times 7.2 \mu \mathrm{m}$. Seta erect, \pm 1.5 $\mathrm{cm}$ long. Capsule brown, erect, cylindrical, may be slightly curved, $\pm 2.68 \mathrm{~mm}$ long and \pm 0.52 $\mathrm{mm}$ in diameter. Spore light brown, $\pm 25 \mu \mathrm{m}$ in diameter.

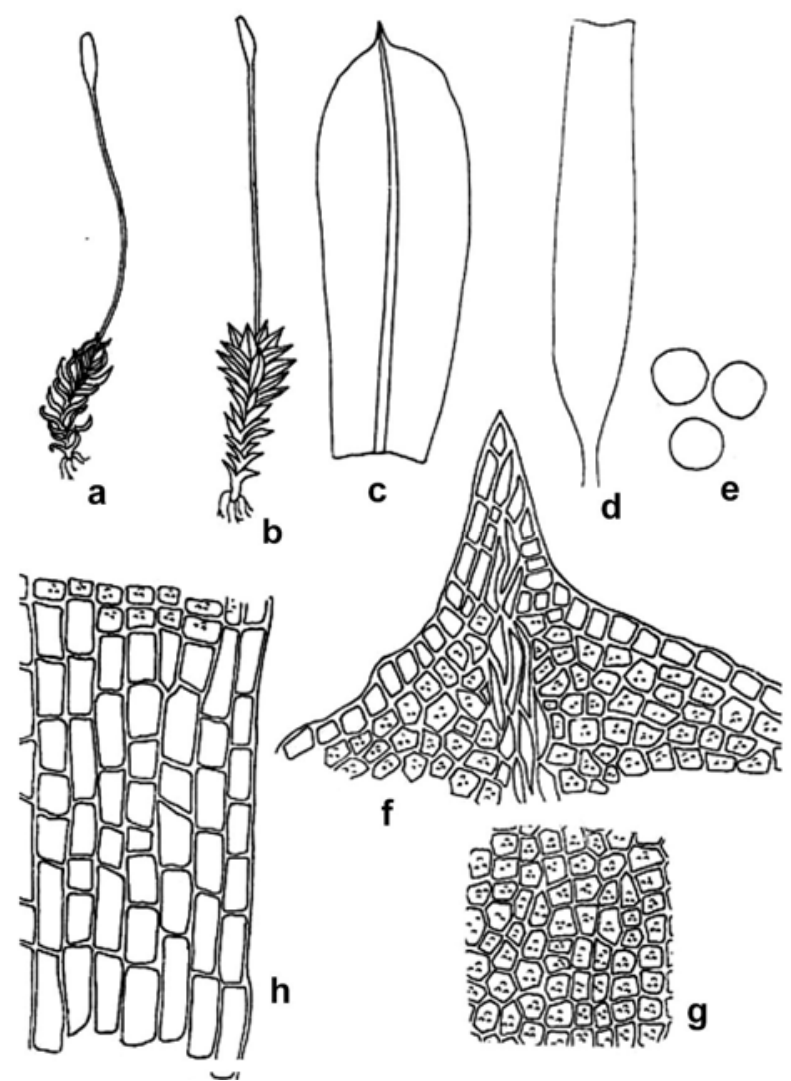

Fig. 3a-h. Hyophila perannulata Ren. et Card. a. Dry plant $(\times 5)$, b. wet plant $(\times 5)$, c. leaf $(\times 15)$, d. capsule without operculum $(\times 15)$, e. spores $(\times 225)$, f. apex of leaf $(\times 225)$, g. middle laminal cells $(\times 225)$, h. Basal cells of lamina $(\times 225)$. 
Specimens examined: Behind the large green house and touching the eastern wall of Cybele part, on cemented structure, Md. Saidur Rahman, 28. 09. 2006, 14, (DUBH)

Distribution: Vietnam, Thailand and India

\section{Hyophila rosea Williams in Bull. Bot. Gard., 8 : 341 (1914)}

Plants dioicous, tufted, green, usually simple, sometimes branched, $\pm 8.5 \mathrm{~mm}$ long and \pm 4.25 $\mathrm{mm}$ broad with leaves. Leaves forming rosette tufts at apex, erectopatent to erect-spreading, lightly crispate and curved when dry, lingulate from a narrower base, $\pm 1.9 \mathrm{~mm}$ long and \pm 0.48 $\mathrm{mm}$ wide in upper part, keeled, sheathing erect base short, apex broadly acuminate, margin usually slightly involutes towards base. Costa brown, papillose, $\pm 68.5 \mu \mathrm{m}$ wide near base, percurrent. Upper laminal cells chlorophyllose, highly multipapillose, obscure, $\pm 6.25 \times 5.58 \mu \mathrm{m}$, hexagonal to round. Basal portion of leaf covered by smooth, pellucid, rectangular cells, $\pm 27.68 \times 10.80 \mu \mathrm{m}$, becoming smaller towards apex and margin. Seta apical, erect, brown to yellow green, $\pm 1.25 \mathrm{~cm}$ long. Capsule erect, brown, cylindrical but wider at base, $\pm 2.13 \mathrm{~mm}$ long and $\pm 0.35 \mathrm{~mm}$ in diameter. Operculum $\pm 0.57 \mathrm{~mm}$ long and sometimes slightly bent to one side. Peristome absent. Spores rounded, $\pm 17.34 \mu \mathrm{m}$ in diameter, light brown, pellucid. Multicellular gemmae arise from leaf axis.

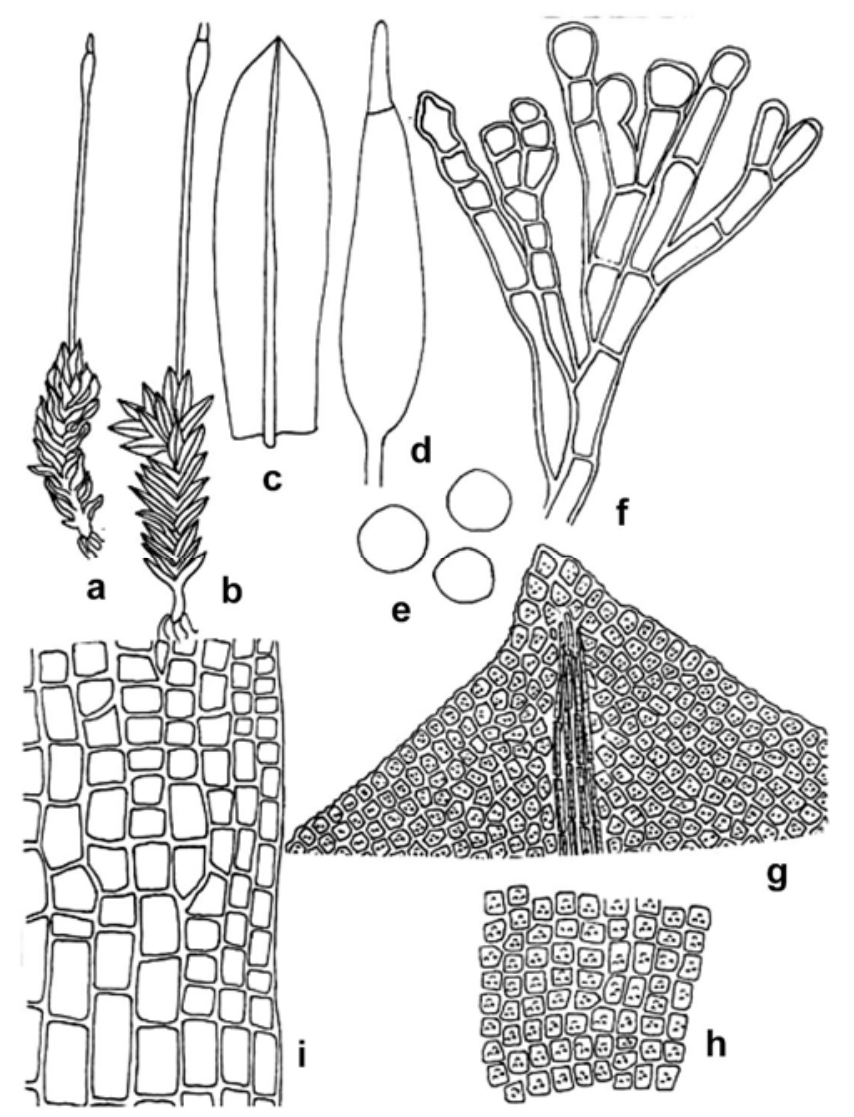

Fig. 4a-h. Hyophila rosea Williams. a. Dry plant $(\times 5)$, b. wet plant $(\times 5)$, c. leaf $(\times 15)$, d. capsule with operculum $(\times 15)$, e. spores $(\times 225)$, f. gemma cluster $(\times 50)$, g. apex of leaf $(\times 225)$, h. middle laminal cells $(\times 225)$, basal cells of lamina $(\times 225)$. 
Specimens examined: West side of the circular structure in Psyche part, on cemented structure, Md. Saidur Rahman, 14. 09. 2006, 03, (DUBH).

Distribution: India, China, Himalayas, Thailand, Peninsula and Philippines.

\section{References}

Banu K 1991. Taxonomic studies on the Acrocarpous mosses of Bangladesh. Ph.D. Thesis. Department of Botany, University of Dhaka, pp. 460.

Banu-Fattah K 1995b. Fissidens hadii Banu-Fattah- A new species from Bangladesh. Bangladesh J. Bot. 24(2): 201-203.

Banu-Fattah K 1998. Bryophytic flora of Chittagong in Bangladesh. Bangladesh J. Plant. Taxon. 5(2): 83-89.

Banu-Fattah K 2001. A comprehensive checklist of the Bryophytes of Bangladesh. Bangladesh J. Plant Taxon. 8: 17-18.

Banu-Fattah K 2005a. Distichophyllum schmidtii Broth. (Hookeriaceae)- A new report from Bangladesh. Bangladesh J. Bot. 34(1): 45-47.

Banu-Fattah K 2005b. Funaria hygrometrica Hedw. (Funariaceae) from Bangladesh. Bangladesh J. Bot. 34(2): 121-124.

Banu-Fattah K and Hadiuzzama S 1993. Taxonomic Studies on the Acrocarpous mosses of Bangladesh. Three most widespread species. Plant for the environment. Proc. $7^{\text {th }}$ Bien. Bot. Conf. Bangladesh Bot. Soc. Dhaka, pp. 111-118.

Banu-Fattah K and Hadiuzzaman S 1994a. Acrocarpous mosses of Bangladesh-I. Family: Polytrichaceae. Bangladesh J. Plant Taxon. 1(1): 87-94.

Banu-Fattah K and Hadiuzzaman S 1994b. A checklist of Acrocarpous mosses of Bangladesh. Bangladesh J. Bot. 23 (2): 225-230.

Banu-Fattah K and Hadiuzzaman S 1995. Acrocarpous mosses of Bangladesh-II. Family: Ditrichaceae. J. Asiat.Soc. Bangladesh. Sci. 21(2): 271-276.

Banu-Fattah K and Hadiuzzaman S 1996a. Acrocarpous mosses of Bangladesh-III. Family: Ditrichaceae. J. Asiat.Soc. Bangladesh. Sci. 22(1): 1-17.

Banu-Fattah K and Hadiuzzaman S 1996b. Acrocarpous mosses of Bangladesh-IV, Family: Leucobryaceae. Bangladesh J. Plant Taxon. 3(1): 45-55.

Banu-Fattah K and Hadiuzzaman S 1996c. Acrocarpous mosses of Bangladesh-VI. Family:Calymperaceae. Bangladesh J. Plant Taxon. 3(2): 59-76.

Banu-Fattah K and Hadiuzzaman S 1997. A new species of Splachnobryum C. Muell. (Splachnaceae) from Bangladesh. Bangladesh J. Bot. 26 (1): 61-64.

Banu-Fattah K and Hadiuzzaman S 1998a. Acrocarpous mosses of Bangladesh-V. Family: Fissidentaceae. J. Asiat.Soc. Bangladesh. Sci. 24(2): 215-249.

Banu-Fattah $\mathrm{K}$ and Hadiuzzaman S 1998b. Acrocarpous mosses of Bangladesh-VII. Family: Pottiaceae. Bangladesh J. Plant Taxon. 5(2): 43-67.

Banu-Fattah K and Hadiuzzaman S 1998c. Acrocarpous mosses of Bangladesh-VIII. Family: Funariaceae. Bangladesh J. Bot. 27(2): 71-87.

Banu-Fattah K and Hadiuzzaman S 1999. Fissidens sylvaticus Griff. var ramosus Banu-a new variety from Bangladesh. Bangladesh j. Bot. 28 (2): 177-179.

Banu-Fattah K and Hadiuzzaman S 2003a. Acrocarpous mosses of Bangladesh-IX. Family:- Splachnaceae. Bangladesh J. Plant Taxon. 10(1): 27-34.

Banu-Fattah K and Hadiuzzaman S 2003b. Acrocarpous mosses of Bangladesh-X. Family: Bryaceae GenusBryum Hedw. Bangladesh J. Bot. 32(2): 107-117.

Banu-Fattah K and Hadiuzzaman S 2004. Acrocarpous mosses of Bangladesh-X. Family: Bryaceae GenusPohlia Hedw. Bangladesh J. Bot. 33(1): 31-34. 
Banu-Fattah K and Hadiuzzaman S 2006a. Acrocarpous mosses of Bangladesh-XI. Family:- Bartramiaceae1. Bangladesh J. Bot. 35(1): 23-29.

Banu-Fattah K and Hadiuzzaman S 2006b. Acrocarpous mosses of Bangladesh-XI. Family:- Bartramiaceae2. Bangladesh J. Bot. 35(2): 91-97.

Banu-Fattah K and Lal J 1998. Occurrence of Pleuridella colei H. Robinson, a monotypic moss from Bangladesh. Bangladesh J. Bot. 27 (2): 147-149.

Gangulee HC 1969-1980. Mosses of Eastern India and adjacent regions. A Monograph. Vol. I-VIII. Book and Allied Pvt. Ltd., Calcutta, India, pp. 2144.

Hadiuzzaman S 1984a. Mosses of Bangladesh-I. A taxonomic study of Fissidens Hedw. Bangladesh J. Bot. 13(2): 147-160.

Hadiuzzaman S 1984b. Mosses of Bangladesh-II. A taxonomic study of Calymperes Sw. Bangladesh J. Bot. 13(2): 161-167.

Hadiuzzaman S 2007. Class: Hepaticopsida and Anthoceropsida. In: Siddiqui KU, Islam MA, Ahmed ZU, Begum ZNT, Hassan MA, Khondker M, Rahman MM, Kabir SMH, Ahmad M, Ahmed ATA, Rahman AKA and Haque EU (eds). Encyclopedia of Flora and Fauna of Bangladesh, Vol. 5. Bryophytes, Pteridophytes, Gymnosperm. Asiatic Society of Bangladesh, Dhaka. Pp 1-38.

Kamruzzaman M 1995. Studies on the genus Riccia of Bangladesh. Ph.D. Thesis, Department of Botany, University of Dhaka, pp.272.

Khatun H 2002. Taxonomic Studies on Pleurocarpous mosses of Bangladesh. Ph.D Thesis, Department of Botany, University of Dhaka, pp.554.

Khatun H and Hadiuzzaman S 1994. Taxonomic studies of some Pleurocarpic mosses of Bangladesh. Bangladesh J. Bot. 23(1): 113-122.

Khatun H and Hadiuzzaman S 1995. Addition to the Pleurocarpic mosses of Bangladesh. Bangladesh J. Bot. 24(2): 183-191.

Khatun $\mathrm{H}$ and Hadiuzzaman S 2003. Pleurocarpous mosses of Bangladesh. Family-Neckeraceae-I. Bangladesh J. Plant Taxon. 10(2): 47-55.

Khatun H and Hadiuzzaman S 2004. Pleurocarpous mosses of Bangladesh. Family-Erpodiaceae. Bangladesh J. Plant Taxon. 11(2): 29-32.

Khatun H and Hadiuzzaman S 2005. Pleurocarpous mosses of Bangladesh. Family-Meteoriaceae and Pterobryaceae. Bangladesh. J. Plant Taxon. 12(1): 53-57.

Khatun $\mathrm{H}$ and Hadiuzzaman S 2006. Pleurocarpous mosses of Bangladesh. Family-Entodontaceae. Bangladesh J. Plant Taxon. 13(2): 131-137.

Khatun H and Hadiuzzaman S 2007a. Pleurocarpous mosses of Bangladesh. Family- Sematophyllaceae. Bangladesh J. Bot. 36(1): 69-80.

Khatun $\mathrm{H}$ and Hadiuzzaman S 2007b. Additions to the Pleurocarpous mosses of Bangladesh. FamilyPlagiotheciaceae. Bangladesh J. Plant Taxon. 14(1): 79-82.

Tixier P 1968. Bryophytae Indosinicae. Dacca Univ. Stud. 15B: 1-14.

(Manuscript received on 4 March, 2013; revised on 20 April, 2013) 